\title{
EFFECT OF DRILL INDUCED NOISE DURING MASTOID SURGERY ON HEARING STATUS OF CONTRALATERAL EAR
}

\author{
Amit Kumar Ray1, Ashutosh Singh², Surendra Kumar Kanawjia ${ }^{3}$, Preeti Kanawjia ${ }^{4}$ \\ 1Senior Resident, Department of ENT, GMC, Ambedkar Nagar, Uttar Pradesh, India. \\ ${ }^{2}$ Surgeon (ENT) Department of ENT, DD Hospital, Azamgarh, Uttar Pradesh, India. \\ ${ }^{3}$ Associate Professor, Department of ENT, GSVM Medical College, Kanpur, Uttar Pradesh, India. \\ ${ }^{4}$ Lecturer, Department of ENT, GMC, Kannauj, Uttar Pradesh, India.
}

\section{BACKGROUND}

ABSTRACT

Hearing morbidity of a healthy ear resulting from drill induced noise while operating the diseased may add on to the actual morbidity arising due to an unhealthy ear. We wanted to study the effect of drill induced noise during mastoid surgery on hearing status of contralateral non-operated ear.

\section{METHODS}

This was a prospective interventional study. 64 patients were enrolled in the study. Audiological tests on patients were done postoperatively after 6 hours, 48 hours, 72 hours, 96 hours and 6 months.

\section{RESULTS}

Most subjects (40.62 \%) were in the age group of $10-20$ years while only $7.81 \%$ subjects were $\geq 40$ years of age. Demographic statistics revealed that majority of the cases were Hindus $(92.12 \%)$ followed by Muslims (7.81\%). PTA revealed that hearing thresholds were not affected at lower frequencies of 250-1000 Hz unlike observations at $4 \mathrm{KHz}, 6 \mathrm{KHz}$ and $8 \mathrm{KHz}$ which reflected a certain change though did not differ significantly between time points. Mean hearing threshold changes, considering all frequencies, were $4.4 \mathrm{~dB}$ after $6 \mathrm{~h}, 4.48 \mathrm{~dB}$ after $48 \mathrm{~h}$, and $9.1 \mathrm{~dB}$, after $72 \mathrm{~h}$ of the surgery which was statistically significant at 6 $\mathrm{KHz}$ and $8 \mathrm{KHz}$. In the present study, the hearing improvement after surgery was considered successful as the air-bone gap closure of $\geq 10 \mathrm{~dB}$ was noted in 52 cases (81.25\%) with the average air-bone gap closure being $15.2 \mathrm{~dB}$ on PTA done at 3 months post operatively.

\section{CONCLUSIONS}

A wise choice of operative technique and improving range and quality of drilling equipment can be helpful in reducing the morbidity load effectively. Tympanomastoid surgery and drilling during ear surgery has the potential to cause significant acoustic trauma and transient sensory hearing loss in the contralateral ear. Though drill-generated noise cannot be reduced to any great extent, still in order to lower the acoustic trauma in an ear surgery to the contralateral ear, parameter of burr and drill must be known preoperatively.

\section{KEY WORDS}

Noise, Mastoid, Hearing

HOW TO CITE THIS ARTICLE: Ray AK, Singh A, Kanawjia SK, et al. Effect of drill induced noise during mastoid surgery on hearing status of contralateral ear. J. Evolution Med. Dent. Sci. 2019;8(26):2115-2118, DOI: 10.14260/jemds/2019/465

\section{BACKGROUND \\ Mastoid bone is the bony prominence that can be felt just behind the ear. It contains a number of air spaces and connects with the air space in the middle ear. For this reason, ear diseases in the middle ear can extend into the mastoid bone. Mastoid disease is potentially life threatening therefore historically the management was focused on creating a safe and if possible dry ear. Today, our aims are higher with a greater emphasis on function. To achieve this, we have three tools that potentiate our success.}

'Financial or Other Competing Interest': None.

Submission 15-05-2019, Peer Review 14-06-2019,

Acceptance 20-06-2019, Published 01-07-2019.

Corresponding Author:

Dr. Surendra Kumar Kanawjia,

Associate Professor and Head,

Department of ENT, GSVM Medical College,

Kanpur, Uttar Pradesh, India.

E-mail: drpreeti2411@gmail.com

DOI: $10.14260 /$ jemds $/ 2019 / 465$

(c) $($ ) $\ominus$
Better knowledge of the anatomy, greater clarity and choice of operative technique and improving range and quality of equipment. The Noise-induced damage and related sensorineural hearing loss during ear surgery are a welldiscussed issue, having the probability between 1.2 and $4.5 \%{ }^{1}$ Despite the fact that noise generated by drilling could easily be transmitted to the contralateral cochlea via bone, postoperative hearing status of the is contralateral ear received less interest. Prolonged noise insult to the contralateral ear can certainly have potential risk for temporary hearing loss.

Since the outer hair cells (OHCs) are the initial target of acoustic trauma, ${ }^{2}$ the damage to OHCs will cause a reduction in otoacoustic emissions (OAEs), and it will be logical to assess the non-operated, normal- functioning cochlea by OAE detection methods to monitor changes caused by mastoid surgery on the contralateral side. The outer hair cells determine overall sensitivity and frequency selectivity of the auditory system. 3,4,5 The expected hearing loss may be missed if pure tone audiometry is utilized.6,7

Drill-induced contralateral temporary hearing loss by changes in amplitudes of distortion product OAEs (DPOAEs), 
longitudinal recovery of this temporary hearing loss has not been studied before. This study was designed to evaluate hearing in the contralateral normal ear before and after the mastoid surgery in a longitudinal manner and find out the duration of this temporary hearing loss. The damage to hearing may be temporary or permanent (As a result of irreversible changes in the cochlea). ${ }^{8}$ Sixty-four patients requiring mastoid surgery in their diseased ears, having contralateral normal ear were thus evaluated in this study. Pure tone audiometry and otoacoustic emissions (OAEs) were utilized for baseline evaluation.

\section{Aims and Objectives}

1. To assess the effect of drill induced noise during mastoid surgery on hearing status of contralateral nonoperated ear.

2. To evaluate whether the deafening effect, if any, is temporary or permanent.

\section{METHODS}

The following study was carried out at E.N.T department of Lala Lajpat Rai and associated hospitals, GSVM Medical College, Kanpur extended over a period of 1 year and 9 months. 64 patients were enrolled in the study. Audiological tests on patients were done postoperatively after 6 hours, 48 hours, 72 hours, 96 hours and 6 months. Patients requiring mastoid surgery in their unilateral diseased ears and having otoscopically and audiologically normal contralateral ear, were enrolled. Informed consent and Institutional ethical clearance were duly taken. 64 patients were enrolled in the study. Detailed clinical history, elaborate general and systemic examination were duly done. Routine blood tests were performed. Audiological tests on patients were done postoperatively after 6 hours, 48 hours, 72 hours, 96 hours and 6 months.

\section{Study Design}

It was a prospective interventional study.

\section{Inclusion Criteria}

- $\quad$ Patients $>6$ years of age.

- Unilateral unsafe chronic suppurative otitis media (CSOM) with normal hearing of contralateral ear.

- Unilateral mastoid abscess with CSOM with normal contralateral ear.

- Unilateral cholesteatoma with CSOM with normal contralateral ear.

\section{Statistical Analysis}

Data was evaluated using SPSS version 23. Descriptive statistics was used for data analysis using indexes like mean and standard deviation. Survival analysis was done using Kaplan Meier test to examine recovery rates. Paired t-test was applied to compare pre and post-op data. Statistical significance was taken with $p$ value $\leq 0.05$

\section{RESULTS}

Most subjects (40.62\%) were in the age group of 10-20 years while only $7.81 \%$ subjects were $\geq 40$ years of age. Demographic statistics revealed that majority of the cases were Hindus (92.12\%) followed by Muslims (7.81\%). PTA revealed that hearing thresholds were not affected at lower frequencies of $250-1000 \mathrm{~Hz}$ unlike observations at $4 \mathrm{KHz}, 6$ $\mathrm{KHz}$ and $8 \mathrm{KHz}$ which reflected a certain change though did not differed significantly between time points. Mean hearing threshold changes, considering all frequencies, were $4.4 \mathrm{~dB}$ after $6 \mathrm{~h}, 4.48 \mathrm{~dB}$ after $48 \mathrm{~h}$, and $9.1 \mathrm{~dB}$, after $72 \mathrm{~h}$ of the surgery which was statistically significant at $6 \mathrm{KHz}$ and 8 $\mathrm{KHz}$

\begin{tabular}{|c|c|c|c|c|c|c|c|c|}
\hline 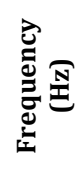 & 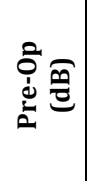 & 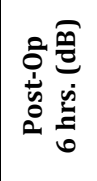 & 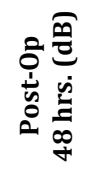 & 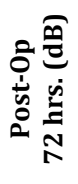 & 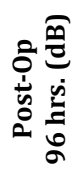 & 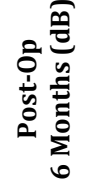 & $\begin{array}{l}\text { คิ } \\
+1\end{array}$ & $=$ \\
\hline 250 & \begin{tabular}{|c|}
5.65 \\
\pm 0.34
\end{tabular} & $\begin{array}{c}5.66 \pm \\
0.56\end{array}$ & $\begin{array}{c}5.45 \pm \\
0.44\end{array}$ & $\begin{array}{c}5 \pm \\
0.38\end{array}$ & $\begin{array}{c}7 \pm \\
0.43\end{array}$ & $\begin{array}{c}7 \pm \\
0.56\end{array}$ & 0.84 & $>0.05$ \\
\hline 500 & $\begin{array}{c}6.35 \\
\pm 0.48 \\
\end{array}$ & $\begin{array}{c}6.35 \pm \\
0.45 \\
\end{array}$ & $\begin{array}{c}6.35 \pm \\
0.49 \\
\end{array}$ & $\begin{array}{l}4.5 \pm \\
0.41 \\
\end{array}$ & $\begin{array}{c}6 \pm \\
0.24 \\
\end{array}$ & $\begin{array}{c}6 \pm \\
0.33 \\
\end{array}$ & 0.71 & $>0.05$ \\
\hline 1000 & \begin{tabular}{|c|}
6.35 \\
\pm 0.44 \\
\end{tabular} & $\begin{array}{c}6.35 \pm \\
0.46\end{array}$ & $\begin{array}{c}6.35 \pm \\
0.38\end{array}$ & $\begin{array}{l}4.7 \pm \\
0.48 \\
\end{array}$ & $\begin{array}{c}7 \pm \\
0.42 \\
\end{array}$ & $\begin{array}{c}7 \pm \\
0.45\end{array}$ & 0.84 & $>0.05$ \\
\hline 2000 & \begin{tabular}{|c|}
6.41 \\
\pm 0.34 \\
\end{tabular} & $\begin{array}{c}6.41 \pm \\
0.57\end{array}$ & $\begin{array}{c}6.66 \pm \\
0.49\end{array}$ & $\begin{array}{l}4.8 \pm \\
0.40\end{array}$ & $\begin{array}{c}6 \pm \\
0.38\end{array}$ & $\begin{array}{c}6 \pm \\
0.42\end{array}$ & 0.66 & $>0.05$ \\
\hline 3000 & \begin{tabular}{|c|}
$7.32 \pm$ \\
0.55 \\
\end{tabular} & \begin{tabular}{|c|}
$7.32 \pm$ \\
0.51 \\
\end{tabular} & $\begin{array}{c}7.11 \pm \\
0.54\end{array}$ & $\begin{array}{c}7 \pm \\
0.40\end{array}$ & $\begin{array}{l}7.3 \pm \\
0.44 \\
\end{array}$ & $\begin{array}{c}7.38 \pm \\
0.43 \\
\end{array}$ & 0.15 & $>0.05$ \\
\hline 4000 & $\begin{array}{l}8.9 \pm \\
0.54\end{array}$ & $\begin{array}{l}9.7 \pm \\
0.34\end{array}$ & $\begin{array}{l}9.8 \pm \\
0.39\end{array}$ & $\begin{array}{l}9.7 \pm \\
0.45\end{array}$ & $\begin{array}{l}8.8 \pm \\
0.44\end{array}$ & $\begin{array}{c}8.89 \pm \\
0.51\end{array}$ & 0.46 & $>0.05$ \\
\hline 6000 & $\begin{array}{l}8.8 \pm \\
0.43\end{array}$ & \begin{tabular}{|c|}
$10.21 \pm$ \\
0.42 \\
\end{tabular} & $\begin{array}{l}9.7 \pm \\
0.50\end{array}$ & $\begin{array}{l}7.9 \pm \\
0.36\end{array}$ & $\begin{array}{c}8 \pm \\
0.34\end{array}$ & $\begin{array}{c}8 \pm \\
0.38\end{array}$ & 0.98 & $>0.05$ \\
\hline 8000 & $\begin{array}{l}9.9 \pm \\
0.32 \\
\end{array}$ & \begin{tabular}{|c|}
12.6 \\
\pm 0.39 \\
\end{tabular} & $\begin{array}{c}11.8 \pm \\
0.41\end{array}$ & $\begin{array}{c}9 \pm \\
0.51 \\
\end{array}$ & $\begin{array}{c}8 \pm \\
0.33\end{array}$ & $\begin{array}{c}8 \pm \\
0.46 \\
\end{array}$ & 1.90 & $>0.05$ \\
\hline \pm SD & 1.5 & 2.4 & 2.2 & 2.1 & 1.0 & 1.0 & & \\
\hline \multicolumn{9}{|c|}{$\begin{array}{c}\text { Table 1. Mean } \pm \text { SD Hearing Threshold (dB) at Different } \\
\text { Frequencies via PTA }\end{array}$} \\
\hline
\end{tabular}

\begin{tabular}{|c|c|c|c|c|c|}
\hline $\begin{array}{l}\text { Frequency } \\
\text { (Hz) }\end{array}$ & $\begin{array}{l}\text { After } \\
6 \text { hrs. }\end{array}$ & \begin{tabular}{|c|} 
After \\
48 hrs.
\end{tabular} & $\begin{array}{l}\text { After } \\
72 \text { hrs. }\end{array}$ & $\begin{array}{l}\text { After } 96 \text { hrs. } \\
\text { \& } 6 \text { Months }\end{array}$ & $\mathbf{p}$ \\
\hline 3000 & 12 & 3 & 0 & 0 & \multirow{4}{*}{$\begin{array}{c}\text { Log Rank (0.458) } \\
\text { Breslow (0.343) } \\
\text { Tarone-Ware } \\
(0.386)\end{array}$} \\
\hline 4000 & 10 & 3 & 0 & 0 & \\
\hline 6000 & 15 & 2 & 1 & 0 & \\
\hline 8000 & 13 & 3 & 2 & 0 & \\
\hline \multicolumn{6}{|c|}{$\begin{array}{c}\text { Table 2. Survival Comparison of Hearing Loss (dB) in Subjects } \\
\text { with Respect to Frequency in PTA }\end{array}$} \\
\hline
\end{tabular}

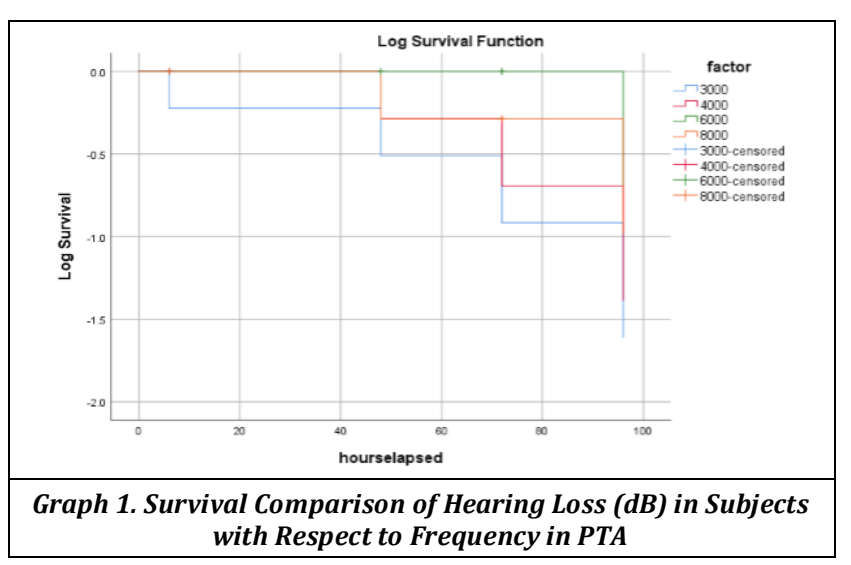

\begin{tabular}{|c|c|c|c|}
\hline $\begin{array}{l}\text { Air Bone Gap } \\
\text { Closure (dB) }\end{array}$ & Frequency & $\%$ Sample & $\begin{array}{l}\text { Average Air Bone Gap } \\
\text { Closure (dB) }\end{array}$ \\
\hline$\geq 10$ & 52 & 81.25 & \multirow{3}{*}{15.2} \\
\hline$<10$ & 12 & 18.75 & \\
\hline Total & 64 & 100 & \\
\hline \multicolumn{4}{|c|}{ Table 3. Hearing Improvement in Subjects } \\
\hline $\begin{array}{l}\text { Of the } 12 \text { cases } \\
\text { graft failure. }\end{array}$ & th less improv & ent, 5 case & s were those who had \\
\hline
\end{tabular}




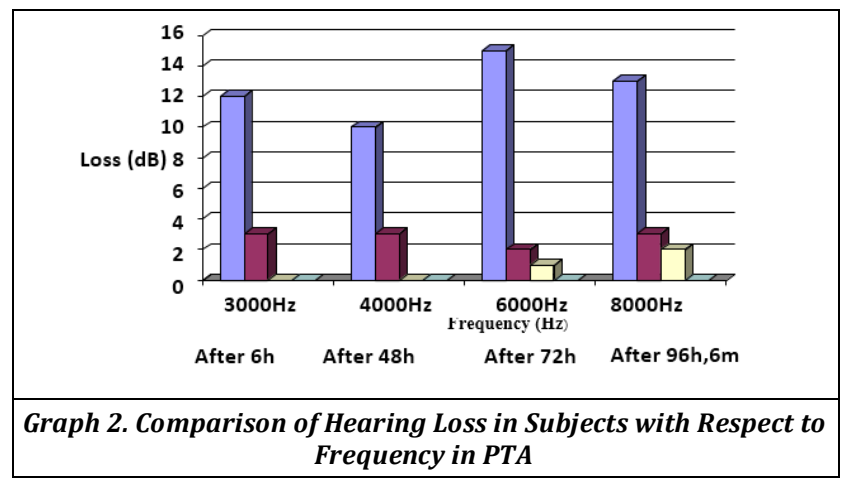

\begin{tabular}{|c|c|c|c|}
\hline \multirow[t]{2}{*}{ Time of Estimation } & \multicolumn{2}{|c|}{$\begin{array}{l}\text { Pre-Post Threshold } \\
\text { difference (Loss) }\end{array}$} & \multirow[t]{2}{*}{ p-Value* } \\
\hline & Mean (dB) & \pm SD & \\
\hline After $6 \mathrm{~h}$ at $2 \mathrm{KHz}$ & -0.69 & 2.87 & 0.12 \\
\hline After $6 \mathrm{~h}$ at $3 \mathrm{KHz}$ & -2.56 & 5.9 & 0.05 \\
\hline After $6 \mathrm{~h}$ at $4 \mathrm{KHz}$ & -3.12 & 4.98 & 0.01 \\
\hline After $6 \mathrm{~h}$ at $6 \mathrm{KHz}$ & -7.89 & 8.1 & 0.06 \\
\hline After $6 \mathrm{~h}$ at $8 \mathrm{KHz}$ & -9.82 & 8.6 & 0.002 \\
\hline After $48 \mathrm{~h}$ at $3 \mathrm{KHz}$ & -10.12 & 4.6 & 0.5 \\
\hline After $48 \mathrm{~h}$ at $4 \mathrm{KHz}$ & -1.76 & 4.7 & 0.00 \\
\hline After $48 \mathrm{~h}$ at $6 \mathrm{KHz}$ & $-1,23$ & 5.1 & 0.00 \\
\hline After $48 \mathrm{~h}$ at $8 \mathrm{KHz}$ & -5.45 & 6.7 & 0.01 \\
\hline After $72 \mathrm{~h}$ at $3 \mathrm{KHz}$ & -4.23 & 5 & 0.45 \\
\hline After $72 \mathrm{~h}$ at $4 \mathrm{KHz}$ & -1.22 & 6 & 0.8 \\
\hline After $72 \mathrm{~h}$ at $6 \mathrm{KHz}$ & -3.24 & 6 & 0.3 \\
\hline After $72 \mathrm{~h}$ at $8 \mathrm{KHz}$ & 4.12 & 8 & 0.06 \\
\hline \multicolumn{4}{|c|}{$\begin{array}{c}\text { Table 4. Mean Hearing Threshold Difference Pre and } \\
\text { Postoperative in PTA }\end{array}$} \\
\hline \multicolumn{4}{|c|}{$\begin{array}{l}\text { p-Value } *>0.05[\text { Insignificant }] \leq 0.05[\text { Significant], Test applied; Paired t- } \\
\text { test. }\end{array}$} \\
\hline
\end{tabular}

\begin{tabular}{|c|c|c|c|}
\hline \multirow{2}{*}{ Estimation Time } & \multicolumn{2}{|c|}{ Paired difference (Loss) } & \multirow{2}{*}{ p Value } \\
\hline & Mean (dB) & $\pm \mathrm{SD}$ & \\
\hline After $6 \mathrm{~h}$ at $2 \mathrm{~Hz}$ & -1.06 & 4.1 & 0.01 \\
\hline After $6 \mathrm{~h}$ at $4 \mathrm{~Hz}$ & $\begin{array}{c}-9.87 \\
\end{array}$ & 8.1 & 0.00 \\
\hline After $6 \mathrm{~h}$ at $6 \mathrm{~Hz}$ & -12.91 & 9.6 & 0.40 \\
\hline After $6 \mathrm{~h}$ at $8 \mathrm{~Hz}$ & -16.83 & 8.8 & 0.02 \\
\hline After $48 \mathrm{~h}$ at $2 \mathrm{~Hz}$ & -11.12 & 7.9 & 0.01 \\
\hline After $48 \mathrm{~h}$ at $4 \mathrm{~Hz}$ & -3.11 & 5.9 & 0.04 \\
\hline After $48 \mathrm{~h}$ at $6 \mathrm{~Hz}$ & -7.01 & 9.1 & 0.00 \\
\hline After $48 \mathrm{~h}$ at $8 \mathrm{~Hz}$ & 7.12 & 8.9 & 0.05 \\
\hline After $72 \mathrm{~h}$ at $4 \mathrm{~Hz}$ & -1 & 3.7 & 0.06 \\
\hline After $72 \mathrm{~h}$ at $6 \mathrm{~Hz}$ & -3.6 & 6.9 & 0.02 \\
\hline After $72 \mathrm{~h}$ at $8 \mathrm{~Hz}$ & -3.82 & 6.4 & 0.01 \\
\hline \multicolumn{4}{|c|}{ Table 5. Pre \& Post-Op Hearing Level difference (SPL) in DPOAE } \\
\hline \multicolumn{4}{|c|}{$\begin{array}{l}\text { p- Value* }>0.05[\text { Insignificant] }, \leq 0.05[\text { Significant], Test applied: Paired } \\
\text { t-test. }\end{array}$} \\
\hline
\end{tabular}

\section{DISCUSSION}

In the present study the minimum age for the study subjects was 7 years and the maximum age was 48 years, mean 27.2 years $\pm \mathrm{SD}=10.23$. Most subjects (40.62 \%) were in the age group of 10-20 years while only $7.81 \%$ subjects were $\geq 40$ years of age. Baradaranfar $\mathrm{MH}$ et al. $(2015)^{9}$ reported the mean age as 35.57 years \pm 11.61 (median 32.5 years, range 16 to 62 years).

Demographic statistics revealed that majority of the cases were Hindus (92.12\%) followed by Muslims (7.81\%). Socioeconomically most cases belonged to social class IV (32.81\%) followed by class V (29.68\%), class III (20.31\%), class II (14.06\%) and class I (3.12\%).

Repeated measure ANOVA with Greenhouse-Geisser correction determined that mean threshold did not differed significantly between time points. (Table 1 )

The mean level of hearing loss based on PTA (Table 4), revealed a significant difference ( $p \leq 0.05)$, after surgery compared to that before surgery at frequencies of 3000$8000 \mathrm{~Hz}$. It also revealed a significant difference $(\mathrm{p} \leq 0.05)$ in mean hearing level at $48 \mathrm{~h} \& 78 \mathrm{~h}$ post operatively at $6 \mathrm{KHz}$ \& $8 \mathrm{KHz}$ compared to that before surgery. Mean hearing threshold changes, considering all frequencies, were $4.4 \mathrm{~dB}$ after $6 \mathrm{~h}, 4.48 \mathrm{~dB}$ after $48 \mathrm{~h}$, and $9.1 \mathrm{~dB}$, after $72 \mathrm{~h}$ of the surgery which was statistically significant at $6 \mathrm{KHz}$ and 8 $\mathrm{KHz}$. There was no significant change in mean hearing threshold at $250 \mathrm{~Hz}, 500 \mathrm{~Hz}, 1000 \mathrm{~Hz}$ and $2000 \mathrm{~Hz}$ (Table 1) based on the PTA. It was similar to a study conducted by Baradaranfar MH et al. (2015).

Furthermore, according to DPOAE analysis (Table 5), the mean difference in the level of hearing found at $6 \mathrm{~h}$ after surgery at frequencies of 2000, 4000 and $8000 \mathrm{~Hz}$ was statistically significant ( $p \leq 0.05)$. Where on one hand, the mean difference in hearing levels at $48 \mathrm{~h}$ after surgery compared to pre-op results were significant at the frequencies of $2000 \mathrm{~Hz}, 4000 \mathrm{~Hz}$, and $8000 \mathrm{~Hz}$; the difference in hearing levels at $72 \mathrm{~h}$ after surgery compared to pre-op results was significant at the frequencies of $6000 \mathrm{~Hz}$, and $8000 \mathrm{~Hz}$.

The survival of hearing loss based on PTA, in nonoperated ears at frequencies of $3000 \mathrm{~Hz}, 4000 \mathrm{~Hz}, 6000 \mathrm{~Hz}$, and $8000 \mathrm{~Hz}$ was $48.2 \%, 37.3 \%, 49.9 \%$, and $48.6 \%, 6 \mathrm{~h}$ after surgery; $12.4 \%, 8.9 \%, 11.1 \%$, and $14.1 \%, 48 \mathrm{~h}$ after surgery; and $0 \%, 0 \%, 2.8 \%$, and $2.3 \%, 72 \mathrm{~h}$ after surgery. At all frequencies at $96 \mathrm{~h}$ and 6 months after surgery, the survival rate of hearing loss was determined to be $0 \%$. (Table 2) (Graph 1)

Baradaranfar MH et al. 2015 in their study also reported similar findings with respect to the survival of hearing loss based on PTA, the survival rate in non-operated ears at frequencies of $3000 \mathrm{~Hz}, 4000 \mathrm{~Hz}, 6000 \mathrm{~Hz}$, and $8000 \mathrm{~Hz}$ was $44.4 \%, 36.4 \%, 51.7 \%$, and $47.4 \%, 24 \mathrm{~h}$ after surgery; $11.1 \%$, $9.1 \%, 10.3 \%$, and $13.2 \%, 48 \mathrm{~h}$ after surgery; and $0 \%, 0 \%$, $3.4 \%$, and $2.6 \%, 72 \mathrm{~h}$ after surgery. At all frequencies at $96 \mathrm{~h}$ after surgery, the survival rate of hearing loss was determined to be $0 \%$. In this regard, survival rate in nonoperated ear based on DPOEA at frequencies of $2000 \mathrm{~Hz}$, $4000 \mathrm{~Hz}, 6000 \mathrm{~Hz}$, and $8000 \mathrm{~Hz}$ was 96.4\%, 94.3\%, 94.3\%, and $99.3 \%, 6 \mathrm{~h}$ after surgery; $74.9 \%, 86.7 \%, 89.2 \%$, and $97.5 \%, 24 \mathrm{~h}$ after surgery; $49.9 \%, 64.0 \%, 70.1 \%$, and $82.4 \%$, $48 \mathrm{~h}$ after surgery; and 25.0\%,33.1\%, 38.8\%, and 54.5\%, 72 $\mathrm{h}$ after surgery, respectively.

In the present study (Table 3) (Graph 3) the hearing improvement after surgery was considered successful as the air-bone gap closure of $\geq 10 \mathrm{~dB}$ was noted in 52 cases (81.25\%) with the average air-bone gap closure being 15.2 $\mathrm{dB}$ on PTA done at 3 months post operatively. In the remaining 12 cases that failed, the graft was not taken up in 5 cases while the other 7 had an improvement $<10 \mathrm{~dB}$.

Regarding patients' personal perception of their hearing status, the similarity in hearing levels before and after surgery at $6 \mathrm{~h}, 48 \mathrm{~h}, 72 \mathrm{~h}$ after surgery was reported in $18.7 \%, 36.5 \%, 47.9$, and $97.1 \%$ of cases respectively.

Doménech et al. reported a measurable hearing loss in the upper limits of the audible frequencies in 9 patients $(37.5 \%)$ and it was considered important in 4 of them (16.7\%). This hearing loss was recorded above the upper frequency limit of conventional audiometer. ${ }^{10}$

Present study recorded that the survival rate of hearing loss was $0 \%$ (Graph 1) for all tested frequencies with no significant difference (Table 2) unlike Baradaranfar MH 2015 who found that after the various individual fluctuations, the 
DPOAE amplitudes remained decreased in some of the patients at the end of the study.

The mean hearing recovery time for non-operated ears based on DPOAE in our study was $57.38 \pm 26.35 \mathrm{~h}(2000 \mathrm{~Hz})$, $64.13 \pm 27.57 \mathrm{~h}(4000 \mathrm{~Hz}) 66.51 \pm 28.26 \mathrm{~h}(6000 \mathrm{~Hz})$, and $76.18 \pm 21.23 \mathrm{~h}(8000 \mathrm{~Hz})$. Likewise, Karatas et al. studied the amplitudes of the OAEs of contralateral normal ears which where was found to be affected immediately after surgery, but showed progressive improvement with full recovery in 72-96 h. None of the patients had permanent deterioration in OAE amplitude. ${ }^{11}$

\section{CONCLUSIONS}

Tympanomastoid surgery and drilling during ear surgery has the potential to cause significant acoustic trauma and transient sensory hearing loss in the contralateral ear. Though drill-generated noise cannot be reduced to any great extent, still in order to lower the acoustic trauma in an ear surgery to the contralateral ear, parameter of burr and drill must be known preoperatively. Otological surgeons must minimize drilling time during surgical management of ear surgery especially in older subjects who are more vulnerable to vibration and noise than younger subjects. ${ }^{12,13}$

\section{REFERENCES}

[1] Tos M, Lau T, Plate S. Sensorineural hearing loss following chronic ear surgery. Ann Otol Rhinol Laryngol 1984;93(4 Pt 1):403-9.

[2] Hall AJ, Lutman ME. Method for early identification of noise - induced hearing loss. Audiology 1999;38(5):277-80.

[3] Dallos P, Cheatham MA. Production of cochlear potentials by inner and outer hair cells. J Acoust Soc Am 1976;60(2):510-12.

[4] Davis H. An active process in cochlear mechanics. Hear Res 1983;9(1):79-90.

[5] Kimberley BP. Applications of distortion-product emission to an otological practice. Laryngoscope 1999;109(12):1908-18.
[6] Tos M, Trojaborg N, Thomsen J. The contralateral ear after translabyrinthine removal of acoustic neuromas: Is there a drill-noise generated hearing loss? J Laryngol Otol 1989;103(9):845-9.

[7] Urquhart AC, McIntosh WA, Bodenstein NP. Drillgenerated sensorineural hearing loss following mastoid surgery. Laryngoscope 1992;102(6):689-92.

[8] Sugisawa T, Ischida A, Hotta S, et al. The effect of 6 $\mathrm{KHz}$ tone exposure on inner ear function of the guinea pig: relation the changes in cochlear microphonics, action potential, endocochlear potential and chemical potential of $\mathrm{K}^{+}$and $\mathrm{Na}^{+}$ions, using a double-barrel glass electrode. Eur Arch Otorhinolaryngol 1994;251(3):154-9.

[9] Baradaranfar MH, Shahbazian H, Behniafard N, et al. The effect of drill-generated noise in the contralateral healthy ear following mastoid surgery: the emphasis on hearing threshold recovery time. Noise Health 2015;17(77):209-15.

[10] Doménech J, Carulla M, Traserra J. Sensorineural highfrequency hearing loss after drill-generated acoustic trauma in tympanoplasty. Arch Otorhinolaryngol 1989;246(5):280-2.

[11] Karatas E, Miman MC, Ozturan 0, et al. Contralateral normal ear after mastoid surgery: evaluation by otoacoustic emissions (mastoid drilling and hearing loss). J Otorhinolaryngol Relat Spec 2007;69(1):1824.

[12] Shone G, Altschuler RA, Miller JM, et al. The effect of noise exposure on the aging ear. Hear Res 1991;56(12):173-8.

[13] Kylen P, Stjernvall JE, Arlinger S. Variables affecting the drill-generated noise levels in ear surgery. Acta Otolaryngol 1977;84(3-4):252-9. 